\title{
MISI GEREJA MENGHADIRKAN KERAJAAN ALLAH DI BUMI
}

Oleh : I Made Priana ${ }^{l}$

\begin{abstract}
.
This article tries to show that the mission of the church is to present or to embody the kingdom of God in this earth. The kingdom of God mission is not church oriented mission but the world oriented mission. The kingdom of God mission is God's mission which is done by Jesus that the world will exist and run as it is designed by God, that is the world under God's sovereignty. As God sent Jesus to present the kingdom of God in this earth, it does likewise Jesus sends the church to actualize the mission of Jesus (John 20:21). Church mission is actualization of Jesus'mission that is by words and deeds demonstrating the values of the kingdom of God that the world will be transformed as it is designed by God.
\end{abstract}

Key Words : Mission, Church, Kingdom, God

\section{Pendahuluan}

Misi yang dipercayakan Yesus untuk dilaksanakan gereja sebagai sarana yang dikehendakiNya, adalah aktualisasi dari perutusan Yesus sendiri. Sebagai aktualisasi perutusan Yesus, maka perutusan gereja harus sejalan dengan perutusan Yesus, yakni untuk memberitakan kerajaan Allah di dunia ${ }^{2}$. Sebagaimana Yesus dalam misi Kerajaan Allah berkarya yang mempunyai dampak pada kehidupan dunia, demikianlah juga sepatutnya gereja berbuat ${ }^{3}$, yakni mengarahkan seluuruh ciptaan kepada kepenuhan kedamaian di dalam Allah (Kolose 1:15). Keberadaan gereja sebagai sarana yang dikehendaki Yesus untuk menolong umat manusiamenuju hidup dalam kerajaan Allah, menunjukkan bahwa misi memberitakan Kerajaan Allah di dunia adalah suatu dimensi yang koeksistensif dalam hakikat gereja. Misi memberitakan kerajaan Allah adalah bagian integral dari keberadaan gereja. Esensi dan tujuan dari misi gereja ialah memberitakan dan mewujudkan kerajaan Allah di dunia ( Markus 3:13, Markus 16:15, Matius 10:1-42).

${ }^{1}$ I made Priana adalah dosen tetap program pasca Sarjana STTNI Yogyakarta. Ia mendapat gelar Sarjana Teologia dari Universitas Kristen Duta Wacana pada tahun 1984, dan mendapat gelar Magister Teologi di Universitas yang sama pada tahun 1998. Pada saat ini, I made Priana sedang menempuh pendidikan Doktor Teologi di Universitas Satya Wacana, Salatiga.

${ }^{2}$ J.Herbert Kane, Understanding Christian Missions, Fourth Edition (Grand Rapids:Baker Book House, 1990), 27.

${ }^{3}$ Edmund Woga CSsR, Dasar-Dasar Misiologi,Cetakan Kelima (Yogyakarta:Penerbit Kanisius, 2006), 113,127. 


\section{Konsepsi Kerajaan Allah}

Kerajaan Allah dikemukakan oleh keempat Injil sebagai pokok utama dalam pewartaan Yesus. ${ }^{4}$ Namun tidak pernah dikatakan atau didefinisikan apakah sebetulnya arti Kerajaan Allah itu. Konsepsi Kerajaan Allah nampaknya bisa diketahui dengan jalan menyelidiki secara sistematis perkataan Yesus tentang Kerajaan Allah itu. Dengan maksud untuk memahami konsepsi Kerajaan Allah, maka pada paper ini dilaporkan hasil bacaan tentang hal-hal sebagai berikut:

\section{Latar Belakang munculnya Istilah Kerajaan Allah}

Injil Matius memakai istilah Kerajaan Sorga sebanyak 33 kali, sedangkan istilah Kerajaan Allah dipakainya hanya 4 kali. ${ }^{5}$ Diantara Injil-Injil, hanya Matius yang memakai istilah Kerajaan Sorga, sedangkan Markus, Lukas dan Yohanes selalu memakai istilah Kerajaan Allah. Terminologi dalam Matius 19:23-24 menunjukkan bahwa istilah Kerajaan Sorga dan Kerajaan Allah di dalam penggunaannya dapat dipertukar tempatkan dan tidak ada perbedaan arti diantara mereka. Istilah Kerajaan Sorga dipakai lebih sering oleh Injil Matius, karena Injil ini ditujukan kepada orang Yahudi yang memang mempunyai kecenderungan untuk menghindari pemakaian nama Allah secara langsung. Sedangkan istilah Kerajaan Allah selalu dipakai oleh Injil Markus, Lukas dan Yohanes karena ketiga Injil ini ditulis untuk orang bukan Yahudi yang tidak memiliki kecenderungan seperti kebiasaan orang Yahudi tersebut di atas. ${ }^{6}$

Kesaksian Injil Matius, pada satu pihak Yesus ternyata memang kerap kali mengikuti kebiasaan Yahudi dalam mengganti kata Allah atau Yahweh dengan salah satu kata lain, misalnya: Sorga $(6: 9,14,7: 11)$, kuasa (26:64) dan hikmat (6:6). Namun pada pihak lain Yesus juga tidak segan menggunakan kata Allah secara langsung (11:19, 19:17). Berkaitan dengan istilah Kerajaan Sorga dan Kerajaan Allah, bisa jadi Yesus memakai istilah Kerajaan Sorga dan boleh jadi juga Ia menggunakan istilah Kerajaan Allah. Namun yang lebih bisa jadi, agaknya Yesus memakai istilah Kerajaan Allah yang kemudian dalam tradisi Matius diganti dengan Kerajaan Sorga. Hal itu diduga demikian, sebab sumber yang tertua yang dipakai oleh Matius yaitu Markus memakai istilah Kerajaan Allah. Begitu juga Injil Lukas yang memanfaatkan Q sebagaimana dimanfaatkan juga oleh Injil Matius tidak mengenal ungkapan Kerajaan Sorga.

Injil-Injil sinoptik (Matius, Markus dan Lukas) melaporkan bahwa pada waktu Yesus mulai melayani, Dia langsung memberitakan Kerajaan Sorga atau Kerajaan Allah sudah dekat. ${ }^{7}$ Ia tidak mewartakan bahwa akan ada suatu Kerajaan Sorga. Kenyataan yang demikian ini menunjukkan bahwa pada jaman Yesus Kerajaan Sorga (Kerajaan Allah)

${ }^{4}$ Matius 4:17, 4:23, 5:20, 6:10, 7:21, 12:28, 13:11, 25:31, 25:34, Markus 1:14-15, Markus 4:30-34, Markus 9:1, Lukas 4:42-44, Lukas 7:18-35, Lukas 9:1-6, Yohanes 18:28-38a

${ }^{5}$ Matius 12:28, 19:24, 21:31, 21:43

${ }^{6}$ Leon Morris, New Testament Theology (Grand Rapids: Zondervan, 1986), 127-128. Bandingkan juga : Johanes B. Bauwer, ed., Bauwer Encyclopedia of Biblical Theology (London: Sheed and Word, 1978), 656.

\footnotetext{
${ }^{7}$ Markus 1:14-15, Matius 4:17, Lukas 4:14-15.
} 
bukanlah suatu istilah yang asing atau baru, melainkan suatu istilah yang sudah diketahui oleh orang. Bahwa Kerajaan Allah adalah suatu istilah yang sudah diketahui oleh orang pada jaman Yesus adalah kenyataan yang wajar, sebab istilah tersebut sudah muncul dalam beberapa kitab-kitab Kesusastraan Yudaisme seperti dalam kitab Targum, kitab Kebijaksanaan Solomo dan kitab Henoch.

Munculnya istilah Kerajaan Allah dalam Kesusastraan Yudaisme, bertujuan untuk menyampaikan ide dalam kitab-kitab Perjanjian Lama bahwa Allah itu hadir dan memerintah di dalam dunia, tetapi dengan cara menghindari pikiran bahwa Allah secara pribadi harus muncul di bumi. Tujuan dan cara ini tampak jelas dalam Targum mengenai Yesaya 24:23 dan Yesaya 40:9, Kitab Yesaya 24:23 yang mengatakan: "Tuhan semesta alam akan memerintah," dalam Targumnya perkataan ini diubah menjadi, "Kerajaan Allah akan memperlihatkan diri". Dalam kitab Yesaya 40:9 ada tertulis, "Lihat Allahmu". Namun dalam Targumnya perkataan ini diubah menjadi: "Kerajaan dari Allahmu telah menjelma". 8

Berdasarkan pada latar belakang munculnya, maka istilah Kerajaan Sorga (Kerajaan Allah) dalam Kesusastraan Yudaisme, sama artinya dengan istilah Allah meraja yang terdapat dalam kitab-kitab Perjanjian Lama. ${ }^{9}$ Dalam Mazmur 145:11-13 kata Kerajaan disejajarkan dengan keperkasaan dan pemerintahan. Oleh karena itu maka istilah Kerajaan Allah mempunyai arti Kuasa atau Pemerintahan Allah yang dinyatakan dalam kedayaan karyaNya.

Paham Kerajaan Allah Bagi Umat Israel Pada Jaman Perjanjian Lama Dan Bagi Umat Yahudi Pada Jaman Yesus

\section{Paham Kerajaan Allah Bagi Umat Israel Pada Jaman Perjanjian Lama}

Kesadaran akan kuasa rajawi Yahweh di Israel rupanya sudah ada sebelum jaman para hakim, sebab dalam nyanyian Musa pada waktu pembebasan dari Mesir sudah dikatakan bahwa Yahweh meraja untuk selama-lamanya (Keluaran 15:18). Kuasa rajawi Allah di Israel pada masa sebelum para hakim mendapat arti yang universal dan juga sekaligus partikularistis. Pengertian yang demikian agaknya dibangun di atas keyakinan bahwa Yahweh adalah pencipta alam semesta dan sekaligus penyelamat umat Israel. Keyakinan ini tampak jelas dari Mazmur 47:2-3 yang mengatakan: "Yahweh yang Maha Tinggi adalah dahsyat, Raja yang besar atas seluruh bumi. Ia menaklukkan bangsa-bangsa ke bawah kuasa kita", dan dari Mazmur 74:12 yang mengatakan: "Engkau, ya Allah, adalah Rajaku dari jaman purbakala, yang melakukan penyelamatan di atas bumi. Engkaulah yang membelah laut dengan kekuatanMu, yang memecahkan kepala ular naga di atas muka air..."

\footnotetext{
${ }^{8}$ Tom Jacobs dan R. Sumadia. Injil Gereja Purba Tuhan Kita Yesus Kristus (Yogyakarta: Kanisius, 1975), 205-206 Bandingkan juga: George Arthur Buttrick, ed., The Interpreter's Dictionary of the Bible (New York: Abingdon Press, 1962), 17.

${ }^{9}$ Keluaran 15:18, Yesaya 24
} 
Pada jaman para hakim dan pada jaman para raja, istilah "Kerajaan Allah" atau "Allah meraja" dipahami oleh umat Israel sebagai kuasa mutlak Allah atas umat-Nya. Paham ini tampak dalam kitab Hakim-Hakim 8:23, I Samuel 8:1-7, I Samuel 8:19-22 dan I Samuel 12:12 yang melukiskan bahwa Kuasa Yahweh itu secara eksplisit dilawankan dengan kuasa politik. Paham ini terlihat juga dari apa yang tertulis dalam I Samuel 10:24, I Samuel 16:21 dan II Samuel 7:12-16 yang menerangkan bahwa sekalipun ada raja-raja politik namun para raja itu selalu dipilih langsung oleh Yahweh sendiri. Paham bahwa Allah berkuasa mutlak atas umatNya terbaca pula dari II Samuel 24:1-17 yang menerangkan bahwa raja Yehuda tidak mempunyai kuasa dari diri sendiri, tetapi melulu karena diberi oleh Yahweh. Ia bisa diprotes oleh rakyat dan bisa dihukum oleh Tuhan bila ia menarik segala kuasa dari Yahweh pada dirinya sendiri.

Pada masa kerajaan politik hancur, Kerajaan Allah (Allah meraja) mendapat arti eskatologis, sehingga dipahami oleh umat Israel sebagai kuasa atau tindakan Allah yang definitif dan terakhir. Kerajaan Allah pertama-tama dipahami sebagai pertolongan dan hiburan dari pihak Yahweh. ${ }^{10}$ Kemudian sejak pembuangan, Kerajaan itu lebih dimengerti sebagai kuasa Allah yang membebaskan umatNya. ${ }^{11}$ Pada masa pembuangan Kerajaan Allah juga mendapat arti yang lebih universal. Yahweh diyakini akan menjadi raja atas seluruh bumi. ${ }^{12}$ Setelah masa pembuangan, Kerajaan Allah mendapat arti yang lebih substansiil tetapi juga menjadi lebih transenden. Allah dipahami akan mendirikan kerajaan yang tak pernah akan dimusnahkan, dan kerajaan itu tidak akan masuk ke dalam kekuasaan bangsa lain. Kerajaan itu akan membinasakan dan menghancurkan segala kerajaan tetapi ia sendiri akan berdiri untuk selama-lamanya. ${ }^{13}$ Kerajaan yang bersifat transenden itu akan diberikan kepada Anak Manusia. ${ }^{14}$

Pada masa kerajaan politik hancur, Kerajaan Allah selalu berarti: kebebasan, penebusan, keselamatan, tidak pernah penindasan atau pemerasan. Juga kalau ditekankan sifat transendennya dan kuasa terhadap kerajaan duniawi, itu hanya mengungkapkan kuasa Allah yang akan menolong umatNya. Terutama dari Yesaya 52:7 terlihat jelas bahwa Kerajaan Allah diyakini, diwartakan dan dinanti sebagai kabar gembira (Injil). Bagi Israel pada masa kerajaan politik hancur istilah Kerajaan Allah mengungkapkan harapan dan kepercayaan akan daya kekuatan Allah yang akan menyelamatkan. ${ }^{15}$

\section{Paham Kerajaan Allah Bagi Umat Yahudi pada Jaman Yesus}

Pada jaman Yesus, situasi hidup bangsa Yahudi adalah tegang disegala bidang: baik di bidang politik, ekonomi maupun agama. Di bidang politik rakyat Yahudi tertekan dan teraniaya secara physik karena diatur dan diperintah oleh para penguasa Roma dengan licik dan kejam. Di bidang ekonomi rakyat kecil Yahudi menderita kemiskinan karena

\footnotetext{
${ }^{10}$ Mikha 2:12-13, Yesaya 40:9-11 Ezra 34:11-19

${ }^{11}$ Yesaya 40:9-11, 52:7, Ezra 20:33, 37, Sefanya 3:15, Zakaria 9:9

${ }^{12}$ Zakaria 14:9, Yesaya 24:33, 51:5, 52:10

${ }^{13}$ Daniel 2:44, 4: 31, 34

${ }^{14}$ Daniel 7:14, 18

${ }^{15}$ Bandingkan Tom Jabocs, Siapa Yesus Kristus Menurut Perjanjian Baru (Yogyakarta: Kanisius,
} 1982), 179. 
mereka dieskploitir, diperas dan diperlakukan tidak adil oleh pihak yang kuat. Di bidang keagamaan umat Yahudi juga sangat tersiksa secara mental karena agama masyarakat Yahudi bersifat formal dan legalistik. Dalam situasi hidup yang demikian, paham Kerajaan Allah oleh masyarakat Yahudi diberi bentuk nasionalistis dan apokaliptis. ${ }^{16}$

Dalam bentuknya yang nasionalistis, istilah Kerajaan Allah diberi arti oleh masyarakat Yahudi, khususnya kaum Zelot, sebagai kemenangan bangsa Yahudi atas bangsa Roma yang ada pada waktu itu menjajah mereka. Kaum Zelot memang sangat giat dalam membebaskan bangsa Yahudi dari kuasa politik orang asing. Kegiatan kaum Zelot sungguh-sungguh suatu jihat. Kaum Zelot selalu siap mengangkat senjata memerangi musuh demi Kerajaan Allah. Kaum Zelot berbuat demikian, karena bagi mereka dengan kebangkitan nasional dan dengan kemenangan bangsa Yahudi atas bangsa-bangsa kafir, Kerajaan Allah akan terwujud. ${ }^{17}$

Dalam bentuknya yang apokaliptis, Kerajaan Allah oleh bangsa Yahudi yang kena pengaruh aliran apokaliptik ${ }^{18}$, diartikan sebagai suatu campur tangan Allah yang akan menggoncangkan kekuatan-kekuatan langit dan yang membangkitkan suatu dunia baru. Kaum apokaliptik mencoba menggambarkan keseluruhan sejarah suci menuju situasi malang sekarang dan melalui itu kepada kepenuhan jaman. Dalam rangka perhatian mereka pada masa mendatang, mereka sering tergoda untuk meramalkan dengan terlalu gegabah tentang pembalasan Allah atas orang-orang bukan Yahudi dan tentang kapan persisnya dunia akan binasa. Kaum apokaliptik juga sering mempergunakan gambarangambaran yang penuh fantasi dan khayal, lukisan secara berlimpah-limpah tentang kebahagiaan eksatologis. ${ }^{19}$

Makna Kerajaan Allah Dalam Misi Yesus.

\section{Dalam Perkataan Yesus Bahwa Kerajaan Allah Sudah Datang}

Di dalam konteks Matius 12:22-35, Lukas 11:14-23 dan Markus 3:20-30, kedatangan Kerajaan Allah berhubungan erat dengan beroperasinya kuasa Yesus di dalam kehidupan seseorang sebagaimana nampak dalam kuasa Yesus mengusir setan. Untuk memahami hubungan ini ada baiknya apabila kita lebih dahulu memahami arti penggunaan kata Kerajaan Allah secara khusus di dalam Injil Matius.

\footnotetext{
${ }^{16}$ Uraian ini didasarkan pada informasi yang didapat dari Donald B. Kraybill, Kerajaan Yang Sungsang (terj. Tobing dan Stepehen Suleeman) (Jakarta: BPK, Gunung Mulia, 1993), hlm 25-72. Dan juga dari David J.Bosch,Transformasi Misi Kristen,Sejarah Teologi Misi Yang Mengubah Dan Berubah,terj.Stephen Suleeman(Jakarta:BPK Gunung mulia,cet.ke-8,2011), 36-41.

${ }^{17}$ Uraian pada alinea ini didasarkan pada informasi yang didapat dari: Nico Syukur Dister, Kristologi Sebuah Sketsa (Yogyakarta: Kanisius, cetakan ke enam, 1994), 57-58.

${ }^{18}$ Apokaliptik adalah sebuah alam pikiran pada bangsa Yahudi, khususnya dari tahun 200 Sebelum Masehi sampai tahun 100 Masehi, yang mementingkan harapan akan akhir jaman dan penghakiman terakhir sebagai puncak wahyu Allah. Pada akhir jaman itu, Allah akan menegakkan pemerintahanNya.

${ }^{19}$ Uraian ini didasarkan pada informasi yang didapat dari: C. Groenen, Peristiwa Yesus (Yogyakarta, Kanisius, Cetakan ke tiga, 1998), hlm 80-81
} 
Di dalam Injil Matius terdapat penggunaan beberapa istilah yang berbeda, namun menunjuk kepada pokok yang sama yaitu Kerajaan Allah. Pertama, ada ungkapan Kerajaan Sorga sebagaimana telah disebutkan di atas bahwa itu muncul sebanyak 33 kali di samping munculnya ungkapan Kerajaan Allah itu sendiri sebanyak 4 kali. Kemudian seperti telah disinggung juga bahwa, nampaknya penggantian nama Allah dengan Sorga itu hanya semata-mata untuk menghindari keseganan menyebut nama Allah dengan sia-sia. Kedua, ada ungkapan Kerajaan Anak Manusia atau Kerajaan Kristus (13:41, 16:28). Ketiga, ada ungkapan Kerajaan Bapa (13:43). Keempat, ada ungkapan Kerajaan saja tanpa tambahan apapun di belakangnya (24:14). Di dalam Injil Matius, sebanyak dua kali perkataan "Kerajaan" tidak ditempatkan sebagai yang diungkapkan oleh Tuhan Yesus, melainkan diungkapkan oleh orang lain. Ini dapat kita lihat misalnya dalam Matius 3:2. Di sini yang menggunakan kata Kerajaan adalah Yohanes Pembaptis. Dan dalam Matius 20: 21, kata "Kerajaan" diucapkan oleh ibu Yakobus dan Yohanes. Berdasarkan pada pemakaian istilah kerajaan tersebut, tampak jelas bahwa pengertian kata "kerajaan" tidak dimengerti pertama-tama sebagai suatu wilayah teritorial, namun dipahami sebagai suatu situasi dimana Allah sendiri hadir dan memerintah. Dengan kata lain, istilah Kerajaan Allah di sini dipahami sebagai pemerintahan Allah ${ }^{20}$. Bahwa kerajaan tidak dimaksudkan sebagai suatu wilayah teritorial, namun sebagai suasana pemerintahan Allah, tampak jelas dalam pengajaran Yesus agar kita berdoa, “ datanglah kerajaanMu, jadilah kehendakMu di bumi seperti di sorga(Matius 6:10).

Menurut Matius 12:22-37 kehadiran pemerintahan Allah terkait erat sekali dengan perbuatan Tuhan Yesus mengusir setan.Tuhan Yesus mengusir setan dengan "kuasa Roh Allah". Sebutan Kuasa Roh Allah itu sendiri rupanya menunjuk kepada kehadiran Allah secara konkrit di dalam kehidupan dan pekerjaan Tuhan Yesus. Kehadiran Allah di dalam Diri Tuhan Yesus ini dimanifestasikan di dalam kuasa perbuatanNya mengusir setan. Dengan kata lain, pengusiran setan itu sendiri merupakan pekerjaan Allah di dalam dan melalui Diri Tuhan Yesus. Oleh sebab itu maka pengusiran setan melalui kuasa dinamis Allah yang bekerja di dalam Diri Tuhan Yesus sebenarnya juga merupakan manifestasi kehadiran Allah yang memerintah, manifestasi kehadiran Kerajaan Allah. ${ }^{21}$

\section{Dalam Jawaban Yesus Kepada Yohanes Pembaptis}

Baik di dalam Matius 11: 2-6, maupun di dalam Lukas 7: 18-23, dikatakan bahwa Yohanes Pembaptis dipenjarakan, sebab ia berani mengecam raja Herodes Antipas dan ratu Herodias. Dalam penjara Yohanes mendengar tentang pekerjaan Yesus, tetapi hal memberi identifikasi kepada Yesus menjadi hal yang agak sukar bagi Yohanes. Yohanes sudah menubuatkan bahwa Yesus akan mengumpulkan gandumNya ke dalam lumbung, membakar debu jerami dalam api yang tak terpadamkan, namun nubuat itu belum dipenuhi oleh Yesus. Dalam keadaan yang demikian, mungkin sekali ada satu hal yang secara khusus menjadi tanda tanya besar bagi Yohanes. Yohanes telah mengikuti teladan nabi

\footnotetext{
${ }^{20}$ Yusak Tridarmanto,Theologia Alkitab II, (Yogyakarta: Diktat Kuliah, Mata Kuliah Theologia Perjanjian Baru, 1997), 10.

${ }^{21}$ Ibid, 10.
} 
Elia, yang berani menentang raja Ahab dan ratu Izebel. Tuhan tidak membiarkan Ahab dan Izebel menangkap Elia. Sedangkan Yohanes Pembaptis sudah lama meringkuk dalam penjara, tetapi Mesias yang sudah datang itu tidak berbuat apa-apa untuk melepaskannya. Di dalam penjara, Yohanes terganggu oleh pengertian yang kurang dan oleh keraguan terhadap Yesus.

Melalui murid-muridNya Yohanes bertanya kepada Yesus, "Engkaulah yang akan datang itu, atau haruskah kami menantikan orang lain? Atas pertanyaan ini Yesus memberikan jawab: "Orang buta melihat, orang lumpuh berjalan, orang kusta menjadi tahir, orang tuli mendengar, orang mati dibangkitkan, dan kepada orang miskin diberikan kabar baik (Matius 11:5, Lukas 7:22). Apa yang tertulis di dalam ayat ini mempunyai persamaan dengan apa yang dinyatakan di dalam Yesaya 35:5-6 dan Yesaya 61:1. "Pada waktu itu mata orang-orang buta akan dicelikkan, dan telinga orang-orang tuli akan dibuka. Pada waktu itu orang lumpuh akan melompat seperti rusa, dan mulut orang-orang bisu akan bersorak-sorak." (Yesaya 35:4-6) "Ia telah mengutus aku untuk menyampaikan kabar baik kepada orang-orang sengsara, dan merawat orang-orang yang remuk hati, untuk memberitakan pembebasan kepada orang-orang tawanan.” (Yesaya 61:1).

Sekalipun ada persamaan yang besar antara perkataan Tuhan Yesus dengan apa yang dinyatakan di dalam Yesaya 35:5-6 dan Yesaya 61:1, namun perkataan Tuhan Yesus itu bukanlah merupakan kutipan langsung dari kitab nabi Yesaya tersebut. Mungkin apa yang kita miliki tentang perkataan Tuhan Yesus dalam Matius 11:2-6 dan Lukas 7:18-22 ini, merupakan hasil pekerjaan Gereja Awal, yang telah menggabungkan kedua perikope dari kitab nabi Yesaya tersebut, dan menempatkannya di dalam mulut Tuhan Yesus, bagaikan Ia sendiri mengatakannya. Dengan penggabungan ini, kita sedikit banyak mendapatkan gambaran kepercayaan Gereja awal tentang siapakah Yesus itu. ${ }^{22}$

Di dalam konteks kitab nabi Yesaya 35:4-6, janji tentang keselamatan Allah yang akan terwujud di dalam pembebasan Israel dari pembuangan Babel mulai diberitakan, dan bahkan sudah berada dalam, proses untuk digenapi. Keselamatan itu sendiri belum datang, karena Yehuda belum dibebaskan dan belum pulang ke Zion. Pada saat Allah melaksanakan pekerjaan penyelamatanNya, dalam wujud pembebasan Yehuda dari perbudakan, akan terjadi pula perbuatan-perbuatan kasih, yaitu mata orang buta akan melihat, telinga orang tuli akan mendengar, orang lumpuh akan berjalan, dan sebagainya. Semua ini dipakai untuk melukiskan akan datangya jaman yang baru, yaitu jaman di mana Allah berkenan kepada umat-Nya dan memberikan perlindungan serta pertolongan kepada umatNya. Para umat Tuhan akan hidup di dalam keadaan damai sejahtera yang dilukiskan dengan tidak adanya orang lumpuh, orang buta dan lain sebagainya. Apa yang dikatakan di dalam kitab nabi Yesaya itu dikenakan oleh Gereja awal di dalam Matius 11:2-6 dan Lukas 7:18-22 pada misi Tuhan Yesus menghadirkan Kerajaan Allah. ${ }^{23}$

Dengan berbuat seperti tersebut di atas, Gereja awal melihat bahwa pekerjaan Tuhan Yesus yang penuh dengan tanda kasih itu sebenarnya merupakan perwujudan pekerjaan Allah yang menyelamatkan. Dengan kata lain, Gereja awal meyakini bahwa di dalam diri Tuhan Yesus, dan melalui segenap misiNya, Allah menggenapkan pekerjaan

\footnotetext{
22 Tridarmanto, Theologia Alkitab II, 13.

${ }^{23}$ Ibid, 14.
} 
PenyelamatanNya bagi manusia. Di dalam Perjanjian Lama karya Penyelamatan Allah merupakan pengharapan Mesianis, yaitu karya Penyelamatan yang akan terwujud di dalam dan melalui kedatangan Mesias. Dengan demikian, maka di dalam keyakinan Gereja awal itu terkandung juga pengakuannya bahwa di dalam diri Tuhan Yesus, janji Mesianis dan Mesias itu tergenapi. Pengakuan yang demikian, tersirat dalam pertanyaan Yohanes: "Engkaukah yang akan datang itu?", yang isinya adalah: "Engkaukah Mesias yang dinantinantikan itu?",24

Dengan menempatkan diri sebagai yang menggenapi janji Mesianis, yang ditandai dengan perbuatan-perbuatan kasih seperti tersebut dalam Matius 11:26 dan Lukas 7:18-22, maka Tuhan Yesus mau menunjukkan bahwa perbuatan kasih yang sedang dilakukanNya adalah menjadi tanda bahwa Kerajaan Allah itu telah hadir mendatangi manusia. Dengan demikian maka misi Yesus dalam menghadirkan Kerajaan Allah diwujudkanNya dengan melakukan perbuatan-perbuatan yang mendatangkan damai sejahtera bagi manusia yang menderita. $^{25}$ Misi Yesus dalam menghadirkan Kerajaan Allah adalah pelayanan mewujudkan nilai-nilai Kerajaan Allah yang bersifat holistik, menyelamatkan, mensejahterakan atau memanusiakan manusi seutuhnya lahir dan batin, badan dan jiwa. Misi Yesus dalam menghadirkan Kerajaan Allah itu adalah misi yang melenyapkan keterasingan, menghancurkan tembok tembok kebencian dan melintasi batas-batas antara individu dan kelompok. ${ }^{26}$

\section{Hakikat Gereja}

Kitab-Kitab Perjanjian Baru khususnya ketiga Injil Sinoptis tidak dimulai dengan meletakkan suatu doktrin tentang Gereja, tetapi dimulai dengan membentangkan bahwa Gereja itu adalah sebuah realitas. Gereja dalam arti yang sesungguhnya pertama-tama dan paling utama adalah suatu peristiwa, suatu kenyataan, suatu peristiwa sejarah. ${ }^{27}$ Menyadari bahwa Perjanjian Baru tidak bermaksud untuk memaparkan suatu uraian sistematis tentang Gereja, maka di dalam meneliti tentang hakikat Gereja, kita perlu menyimak cara hidup para murid Tuhan Yesus sebagaimana dikhendakiNya.

Laporan Injil Sinoptis tentang kisah-kisah yang memperlihatkan hakikat gereja dapat dikemukakan sebagai berikut:

\section{Dari Kisah Yesus Memanggil Murid-murid yang Pertama}

Narasi tentang Yesus memanggil murid-murid yang pertama cukup sistematis. Dalam narasi ini terdapat dua kisah panggilan yaitu : Pertama, panggilan Simon dan Andreas. Kedua, panggilan Yakobus dan Yohanes. Ada tiga fase penting dalam setiap

\footnotetext{
${ }^{24}$ Ibid.

25 Tridarmanto, Theologia II, 14.

${ }^{26}$ Bosch, Transformasi Misi Kristen, 41-44

${ }^{27}$ Kung, The Church (New York: Garden City, 1976), 23.
} 
peristiwa panggilan yakni: Fase pertama pertemuan $^{28}$, dicatat waktu dan tempat pertemuan, dua bersaudara disebut dengan nama pribadi, lalu pekerjaan mereka. Fase kedua ialah kata undangan Yesus. ${ }^{29}$ Fase ketiga, jawaban kesediaan segera untuk mengikuti Yesus. ${ }^{30}$

Pada fase pertama dari panggilan yakni pertemuan diterangkan bahwa pertemuan antara Yesus dengan dua pasang bersaudara Simon dan Andreas, Yakobus dan Yohanes terjadi ketika Yesus "sedang berjalan di tepi danau Galilea". Keterangan ini membawa arti bahwa panggilan terjadi ketika Yesus terlibat dalam peristiwa kehidupan mereka seharihari. Panggilan murid-murid pertama bukan terjadi dalam konteks sakral di Bait Allah seperti misalnya dalam Perjanjian Lama (Yesaya 6:1-13) melainkan dalam konteks profan, di tepi danau. Yesus menjumpai murid-murid pertama dalam kehidupan sehari-harian mereka, yakni di tengah-tengah pekerjaan mereka, yaitu ketika mereka sedang menjala ikan.

Pada fase pertama dari panggilan juga diterangkan bahwa Yesus melihat dua orang bersaudara. Kata yang diterjemahkan dengan melihat adalah "ciden". Kata ini memang berarti melihat, tapi bukan sekedar melihat sambil lalu tanpa perhatian, melainkan memandang dengan tatapan yang menerobos mencapai situasi batin manusia yang dipandang. ${ }^{31}$ Yesus memandang Simon dan Andreas seperti Allah dalam Perjanjian Lama memandang Nuh (Kejadian 7:1). PandanganNya bukanlah pandangan yang netral melainkan pandangan untuk campur tangan, membebaskan, memilih dan memberikan tugas. Disini menyatakan unsur asasi panggilan para murid, yakni bahwa panggilan itu adalah inisiatif dari Yesus.

Pada fase kedua dari panggilan yakni undangan Yesus diterangkan bahwa Yesus mengundang murid-murid yang pertama dengan mengatakan kepada mereka: "Datang ikutlah Aku dan Aku akan menjadikan kamu penjala manusia." Perkataan Yesus ini adalah suatu perintah bukan suatu perundingan atau diskusi. Melaluinya Yesus mengundang murid-murid yang pertama masuk ke dalam gerakanNya. Ucapan "datang ikutlah Aku" menunjukkan bahwa dalam proses panggilan menjadi murid Yesuslah pengambil inisiatif, bukan para murid yang menawarkan diri. Dalam Matius 8:18-22, ${ }^{32}$ ketika seorang ahli Taurat menawarkan diri untuk mengikut Yesus, Yesus agaknya tak begitu antusias dengan tawarannya dan menjawab dengan membeberkan betapa beratnya mengikuti Yesus, seakan-akan satu penolakan implisit. Yang menawarkan diri tidak diterima Yesus.

Dibalik ungkapan "ikutlah Aku" nampaknya juga terkandung gagasan Yahudi tentang para murid yang mengikuti rabinya. Mereka tak hanya mendengar pengajaran guru, melainkan sungguh mengikuti dalam arti hidup dan mengalami kebersamaan dengan gurunya. ${ }^{33}$ Demikian juga Yesus mengundang calon murid untuk hidup bersama denganNya, masuk ke dalam hubungan mesra denganNya. Dalam hal ini panggilan menjadi murid Yesus pada tempat pertama, bukan berarti mendengar sejumlah instruksi

\footnotetext{
${ }^{28}$ Matius 4:18, 21, Markus 1:16, Lukas 5:1-3

${ }^{29}$ Matius 4:19, 21, Markus 1:17, 20, Lukas 5:4-10

${ }^{30}$ Matius 4:20,2, Markus 1:18, 20, Lukas 5:11

${ }^{31}$ Guido Tisera, Jemaat Kerajaan Sorga (Ende: Nusa Indah, 1991), 62.

${ }^{32}$ Bandingkan Lukas 9:57-62

${ }^{33}$ D.A Carson, "Mathew" dalam Frank E. Gaebelem ed., The Expositor's Bible Commentary Vol. 8 (Grand Rapids: Zondervan, 1984), 119
} 
Yesus atau mengikuti sejumlah peraturan dari Yesus, tetapi hidup di dalam persekutuan dengan Yesus secara pribadi. Panggilan menjadi murid Yesus berarti hidup dan tinggal bersama Yesus. $^{34}$

Pada fase terakhir dari panggilan yakni jawaban mereka yang terpanggil diterangkan bahwa Simon dan Andreas segera meninggalkan jalannya dan mengikuti Yesus, Yakobus dan Yohanes segera meninggalkan perahu serta ayahnya lalu mengikuti Yesus. Dalam ungkapan "meningalkan" dan "mengikuti" agaknya yang terjadi bukan perubahan pekerjaan tetapi perubahan kepentingan orientasi hidup. Mereka yang menjawab panggilan Yesus ini, rupanya mengerjakan pekerjaan mereka sehari-hari dan tetap memiliki keluarga, tetapi mereka menempatkan itu semua tidak lagi terutama dan pertama pada kepentingan mereka melainkan pada kepentingan Yesus. ${ }^{35}$ Itu diduga demikian karena para murid dipanggil oleh Yesus bukan untuk digaji malah harus memberi $^{36}$ dan ketika mereka telah menjadi murid, mereka hidup berkeluarga (bandingkan Matius 8:14).

Dari narasi tentang Yesus memanggil murid-murid yang pertama, tampak jelas bahwa Yesuslah yang pertama memanggil. Panggilan bukanlah hak para murid. Tujuan utama panggilan ialah hidup bersama dengan Yesus. Karena inti panggilan adalah Yesus, maka mutlak perlu membina hubungan tetap dengan Yesus. Menjadi murid atau menjadi Gereja berarti menempatkan semua yang dipunya dan dikerja terutama dan pertama pada kepentingan Yesus.

\section{Dari Narasi Tentang Yesus Mengutus Kedua Belas Muridnya}

Perikop pada Matius 10:5-15, Markus 6:6 ${ }^{\mathrm{b}}-13$, Lukas 9:1-6 adalah sebuah narasi tentang wejangan Yesus untuk kedua belas muridNya yang diutus sebagai missionaris. Wejangan ini muncul sesudah Yesus berbicara tentang orang banyak yang terlantar seperti domba tanpa gembala (Matius 9:36-38) dan setelah Ia memanggil kedua belas muridNya (Matius 10:1-4, Markus 3:13-19, Lukas 6:12-16). Melalui khotbah ini Yesus memberikan petunjuk bagaimana seharusnya kedua belas murid yang diutus sebagai missionaris itu hidup, apa yang mereka harus kerjakan dan apa yang mereka perlu bawa.

Membaca secara keseluruhan amanat perutusan Yesus ini, dapat diketahui bahwa murid Yesus adalah seorang yang diutus pergi oleh Yesus untuk mendapatkan orang lain. Ungkapan-ungkapan yang dipakai oleh ketiga Injil Sinoptis seperti : “diutus”, "janganlah pergi di jalan bangsa lain dan janganlah masuk ke dalam kota orang Samaria", "pergilah kepada domba-domba yang hilang dari umat Israel", "pergilah dan beritakanlah", "sembuhkan orang sakit", "janganlah kamu membawa emas atau perak", "keluarlah dan tinggalkanlah"; menunjukkan bahwa daya gerak murid Yesus sebagai seorang tuusan sangat dinamis. Ungkapan-ungkapan tersebut di atas juga memperlihatkan bahwa hakikat

${ }^{34}$ Guido Tisera, "Faham Gereja Menurut Injil Matius" dalam Orientasi Baru Pustaka Filsafat dan Teologi no 2 (Yogyakarta: Kanisius, 1988), 93.

${ }^{35}$ Sinclair Ferguson, Understanding The Gospel (Eastbourne: Kingsway Publications, 1989), 3132.

${ }^{36}$ Matius 14:16, Markus 6:37, Lukas 9:13 
hidup murid Yesus sebagai missionaris adalah selalu pergi demi keselamatan orang lain. Selalu harus pergi adalah sikap dasar seorang murid Yesus. Kecemasan akan keselamatan orang lain adalah kecemasan seorang murid Yesus. ${ }^{37}$ Hidup dalam persekutuan dengan Yesus, mencipatakan adanya tanggung jawab terhadap hidup orang lain sebagai sesama. Hal itu patut dihayati sebab kita tidak mungkin hidup sejahtera dan damai tanpa hidup dengan orang lain sebagai sesama. ${ }^{38}$

Kemudian ketika berbicara tentang sasaran perutusan dikemukakan: "janganlah kamu pergi di jalan bangsa lain dan janganlah kamu masuk ke dalam kota orang-orang Samaria, tetapi sebaliknya pergilah kamu ke domba-domba yang hilang dari rumah Israel”. Ucapan Yesus ini bukanlah dalam konteks katekese tentang misi, melainkan dalam konteks wejangan yang bericara mengenai tugas dan nasib murid Yeus sebagai missionaris. Karena demikian keadaannya, maka ucapan ini bukan menerangkan bahwa misi para murid itu bersifat partikularistis yaitu bagi Israel saja, tetapi memperlihatkan bahwa misi mereka kepada Israel menjadi lambang dari misi mereka yang kemudian, yaitu misi semesta kepada bangsa-bangsa. ${ }^{39}$

Pengutusan juga berisi keterangan tentang pokok-pokok warta perutusan. Keterangan tersebut berunyi: "pergilah dan beritakanlah: Kerajaan Sorga sudah dekat. Sembuhkanlah orang sakit, bangkitkanlah orang mati, tabirkanlah orang kusta, usirlah setan-setan. Kamu telah memperolehnya dengan cuma-cuma, karena itu berikanlah pula dengan cuma-cuma." Pokok pewartaan yang harus diberitakan oleh para murid pada dasarnya tak berbeda dari pewartaan Yesus sendiri. ${ }^{40}$ Keadaan yang demikian ini mempunyai arti bahwa dalam misinya, para murid meneruskan apa yang sudah atau terlebih dahulu telah dilakukan oleh Yesus sendiri. Para murid bukan mewartakan ajaran sendiri, melainkan ajaran Yesus. Dalam pewartaannya, para murid bukan menghadirkan kerajaan sendiri, melainkan Kerajaan Sorga. Dalam memberitakan Kerajaan Sorga, para murid tidak hanya mewartakan dengan perkataan, melainkan juga dengan perbuatan. Para murid harus memberitakan bahwa Kerajaan Sorga itu sudah datang, sudah dirasakan pengaruhnya, dalam penyembuhan orang sakit, pentahiran orang kusta pembangkitan orang mati. Dalam memberitakan Kerajaan Sorga dengan perkataan dan perbuatan, para murid harus menghadirkan peradaban Kerajaan Sorga itu demi kebahagiaan sesama.

Dalam perikop perutusan, Yesus juga memberikan petunjuk tentang cara hidup seorang missionaris yang diutus. "Janganlah kamu membawa emas atau perak atau tembaga dalam ikat pinggangmu. Janganlah kamu membawa baju dua helai, kasut atau tongkat, sebab seorang pekerja patut mendapat upahnya." Petunjuk ini sangat radikal namun ia harus dimenegrti dalam konteks orang Yahudi pada jaman Yesus. Pada jaman Yesus orang Yahudi dikenal sebagai orang yang suka menjamu, menerima tamu, sehingga murid-murid diharapkan tak perlu cemas untuk membawa banyak barang dalam perjalanan. Para murid harus memusatkan perhatiannya pada misi mewujudkan Kerajaan

${ }^{37}$ Tisera, Jemaat Kerajaan, 66-67.

38 Victor I. Tanja,"Perjumpaan Gereja Dengan Agama-Agama Lain" dalam Chris Hartono ed.,Perjumpaan Gereja di Indonesia Dengan Dunianya Yang Sedang Berubah,(Jakarta:Persetia,1995), 21.

${ }^{39}$ Jack Dean Kingsbury, Injil Matius Sebagai Ceritera, pen. Wenas Kalangit (Jakarta: BPK Gunung Mulia, 1995), 180.

${ }^{40}$ Matius 4:17, Markus 1:15, Lukas 4:14-19 
Allah. Petunjuk Yesus ini mempunyai implikasi bahwa seluruh semangat hidup seorang missionaris adalah semangat tak bergantung pada harta benda. Hidup seorang missionaris hendaknya tak memberi kesan sebagai pemburu harta. Melalui petunjuknya, Yesus juga secara implisit mengemukakan di sini tentnag pentingnya penyaksian hidup miskin dihadapan Allah, yaitu satu cara hidup di mana dapat terlihat dan terungkap sikap bergantung pada kebaikan dan penyelenggaraan Allah. Sikap mementingkan harta akan memberi kesan kurang percaya pada kebaikan Allah yang cuma-cuma itu. Petunjuk Yesus tentang cara hidup seorang misionaris juga memiliki makna, agar setiap missionaris yang diutus hendaknya percaya kepada kebaikan orang lain, serta menghargai kebaikan itu, betapapun kecilnya.

Mempelajari narasi tentang Yesus mengutus kedua belas muridNya, dapat diketahui bahwa menjadi murid atau menjadi Gereja pada hakikatnya adalah menjadi orang yang menerima tugas perutusan. Tugas perutusan itu bukanlah tambahan tapi hakiki bagi Gereja. Tugas perutusan itu adalah untuk mewartakan Kerajaan Allah. Di dalam mewartakan Kerajaan Allah, para murid harus memberitakannya dengan perkataan dan tindakan demi keselamatan semua orang. Di dalam mewartakan Kerajaan Sorga itu, para murid patut mewujudkan peradaban dari Kerajaan Allah itu demi kedamaian dunia. Dalam rangka menunaikan tugas perutusannya, para murid dituntut untuk memusatkan perhatiannya mendatangkan Kerajaan Allah di bumi.

\section{Dari Kisah Tentang Nasib Murid-murid yang Diutus}

Susunan teks Matius 10:16-25 cukup sistematis. Ia dibuka dengan pokok pikiran sebagaimana tertulis dalam ayat 16: "Lihat, Aku mengutus kamu seperti domba ke tengahtengah serigala, sebab itu hendaklah kamu cerdik seperti ular dan tulus seperti merpati." Lalu menyusul ajakan umum dalam ayat 17 a dan ramalan profetis tentang penganiayaan yang akan menimpa dalam ayat $17 \mathrm{~b}-18$. Dalam ayat $19-23$ terdapat tiga satuan masingmasing dimulai dengan mengemukakan bentuk penganiayaan, disusul ajakan Yesus dan ditutup dengan janji. Perikop diakhiri dengan perbandingan antara murid dan guru, hamba dan tuan yang senasib dalam ayat 24 dan 25. Perikop sangat didominasi oleh ajakan Yesus untuk bertekun dalam situasi penuh tantangan.

Dalam perikop 10:5-15 Yesus berharap agar para murid percaya akan kebaikan hati banyak orang yang dijumpai dalam perutusan. Namun dalam perikop 10:16-25 Yesus cukup realistis. Ia mengatakan apa adanya. Ia berkata kepada para muridnya: "Lihat, Aku mengutus kamu seperti domba ke tengah-tengah serigala." Dengan berkata demikian, Yesus memberi peringatan ("lihat" adalah nada peringatan) bahwa utusan-utusan Yesus berada dalam bahaya. Mereka memang diharapkan supaya sukses, yakni misi mereka dijawab dan didukung oleh orang-orang. Namun penolakan dan ancaman terhadap misi mereka bahkan terhadap diri mereka sendiri akan selalu ada. Penolak dan pengancam itu adalah para pemimpin Yahudi. Agaknya merekalah yang dimaksud dengan serigala itu, sebab sikap mereka adalah seperti serigala bukan mengayomi masyarakat melainkan 
memangsanya. ${ }^{41}$ Di dalam menghadapi penolakan dan ancaman yang selalu ada, Yesus menasihatkan pada muridNya supaya cerdik seperti ular dan tulus seperti merpati. Kata cerdik disini "fronimoi" bukan berarti cerdik buruk melainkan pintar dan bijaksana. Dengan perkataan ini, Yesus memberi nasihat supaya mereka mencoba memakai kata-kata dan tindakan-tindakan yang bijaksana supaya mereka dapat luput dari bahaya. Tetapi dengan serentak sifat burung merpati, yaitu ketulusan, harus tetap dipelihara. Melalui nasihat yang demikian ini, para murid tidak disarankan untuk memilih konfrontasi, tidak pula perjuangan mati-matian, melainkan supaya bertindak sesuai situasi. Dalam tugas perutusannya, para murid diingatkan bahwa ada waktunya mereka harus berhati-hati tetapi ada pula waktunya mereka meski berprinsip. Dalam tugas perutusan, para murid harus bersikap pragmatis dan realistis.

Menyimak kisah nasib murid-murid yang diutus, didapat pengertian bahwa tantangan dan penderitaan adalah bagian dari perutusan murid-murid. Dalam situasi yang demikian pengalaman bersama Yesus mutlak penting untuk dapat bertahan. Para murid adalah orang-orang yang senasib dengan Yesus yang menderita. Jaminan para murid bukanlah pada fasilitas melainkan pada Yesus sendiri. Sebagai murid Yesus, Gereja terpanggil untuk rela berkorban justru rangka menghadirkan Kerajaan Allah, yaitu membangun peradaban yang melenyapkan kebencian.

\section{Dari kisah pengakuan Petrus}

Pengakuan Petrus sebagaimana tertayang dalam Injil-Injil Sinoptis adalah bahwa Yesus itu "Mesias Anak Allah yang hidup." Gelar "Allah yang hidup" adalah gelar yang biasa dikenakan untuk Allah (Mazmur 42:3), yang berfungsi mempertentangkan antara Allah yang dikenal Israel dengan berhala-berhala. Kemudian gelar "Anak Allah" adalah gelar yang sudah dikenakan untuk Mesias (Mazmur 2:7) karena sesuai dengan nubuatnubuat yang terdapat di dalam kitab-kitab Perjanjian Lama seperti di dalam kitab Yesaya 9:1-6, 11:1-10, 42:1-9; Mikha 5:1-4: Mesias memang adalah hamba Allah yang akan menguasai seluruh dunia dan membawa keselamatan bagi semua bangsa. Jadi dengan mengatakan bahwa Yesus adalah Mesias, Anak Allah yang hidup, Petrus mengakui bahwa Yesus adalah hamba Allah yang memiliki hubungan istimewa dengan Allah dalam rangka karya penyelamatan Allah di dunia ini. ${ }^{42}$ Bahwa Yesus adalah Mesias tidak sama dengan Mesias yang dinantikan orang Yahudi. Mereka menantikan Mesias sebagai raja yang akan memusnahkan musuh-musuh Israel.

Menanggapi pengakuan Petrus, Yesus berkata kepada Petrus: "Berbahagialah engkau Simon bin Yunus sebab bukan manusia yang menyatakan itu kepadamu, melainkan BapaKu yang di Sorga." Perkataan Yesus ini menunjukkan bahwa pengakuan Petrus adalah pengakuan yang benar dan diterima. Perkataan Yesus ini juga menunjukkan bahwa Petrus bisa sampai kepada pengakuannya itu, adalah hanya karena dinyatakan oleh Allah sendiri.

\footnotetext{
${ }^{41}$ Tisera, Jemaat Kerajaan Sorga, 71

42 R.T. France, "Matthew" dalam Leon Morris, ed., The Tyndale New Testament Commentaries (Leicester: Inter Varsity Press, 1985), 253.
} 
Dalam merespon pengakuan Petrus, Yesus juga berkata kepada Petrus: "Engkau adalah Petrus dan di atas batu karang ini, Aku akan mendirikan JemaatKu dan alam maut tidak akan menguasainya. Kepadamu akan kuberikan kunci Kerajaan Sorga. Apa yang kau ikat di dunia ini akan terikat di Sorga dan apa yang kau lepaskan di dunia ini akan terlepas di Sorga." Tanggapan Yesus yang berbunyi: "Di atas batu karang ini Aku akan mendirikan GerejaKu," mempunyai arti bahwa di atas pengakuan seperti pengakuan Petrus, Yesus mendirikan GerejaNya. Dalam hal ini Petrus yang dengan keinsafan penuh mengakui Yesus sebagai Mesias, merupakan batu yang pertama dari Gereja dan kemudian banyak batu yang lain akan ditambah sampai menjadi suatu bangunan yang besar. ${ }^{43}$

Dalam kalimat yang berbunyi: "alam maut tidak akan menguasainya." Yesus agaknya mau menyatakan bahwa kematian tidak akan bisa menghancurkan Gereja. Itu demikian karena Gereja adalah orang-orang yang memiliki persekutuan dengan Yesus Kristus. ${ }^{44}$ Sebagaimana Yesus Kristus telah bangkit dan hidup mengalahkan kuasa maut yaitu kematian, maka demikian pulalah orang-orang yang percaya kepada Yesus akan bangkit dan hidup selamanya walaupun mereka sudah mati secara biologis (Yohanes 11:25-26). Kemudian kalimat yang berbunyi: "Kepadamu akan kuberikan kunci Kerajaan Sorga," sama jiwanya dengan perkataan dalam Yesaya 22:22. Kunci rumah Daud ditaruh ke atas bahu Elyakim yang berarti bahwa dia boleh mengijinkan orang-orang yang mau masuk. Yesus memperbandingkan Kerajaan Sorga dengan istana, sehingga perkataanNya kepada Petrus mempunyai makna bahwa Petrus bertangung jawab untuk membawa orangorang masuk ke dalam Kerajan Sorga. Tanggung jawab Petrus untuk membawa orangorang ke dalam Kerajaan Sorga, tampak dalam pelayanannya di hari Pentakosta (Kisah Para Rasul 2). Melalui khotbahnya Petrus membuka pintu Kerajaan Sorga bagi beribu orang yang rela menerima isi khotbah Petrus itu. Jadi Petrus menjadi juru kunci Kerajaan Sorga atau bertanggung jawab untuk membawa orang-orang masuk ke dalam Kerajaan Sorga melalui Injil yang dikhotbahkannya.

Melalui kata-kataNya yang menyatakan bahwa apa yang Petrus ikat di dunia ini akan terikat di Sorga, dan apa yang Petrus lepaskan di dunia ini akan terlepas di Sorga, Yesus memaksudkan bahwa Petrus yang bertanggung jawab untuk membawa orang-orang masuk ke dalam Kerajaan Sorga, juga mempunyai kuasa dari Tuhan untuk 24esame larangan yang tepat dan ijin yang tepat. Maksud Yesus diduga demikian, karena pada jaman Tuhan Yesus sebagaimana tampak dalam tulisan-tulisan para rabi istilah "mengikat" biasanya berarti melarang perbuatan-perbuatan tertentu dan istilah "melepaskan" seringkali berarti mengijinkan perbuatan-perbuatan yang tertentu. ${ }^{45}$ Karena kuasa itu didapat Petrus dari Tuhan, maka pernyataan Yesus kepada Petrus seperti tersebut di atas, tidak berarti bahwa apa yang Petrus putuskan secara bebas akan disahkan oleh Tuhan, melainkan apa yang Petrus putuskan berasal dari Tuhan, diberikan kepada Petrus untuk dilakukan. ${ }^{46}$ Bahwa Petrus mempunyai kuasa untuk mengijinkan sesuatu dalam pengertian

43 Jack Dean Kingsbury, "The Figure of Peter in Matthew's Gospel as a Theological Problem". Journal of Biblical Literature (no. 98, 1979), 67-83.

${ }_{4}$ Sherman E. Johnson, "The Gospel According to ST. Matthew" dalam G.A. Buttrick, The Interpreter's Bible (New York: Abiongdon Press, 1951), 452-453.

${ }^{45}$ Willoughby C. Allen, A Critical And Exegetical Commentary On The Gospel According To S. Matthew (Edinburgh: T \& T. Clark, 1951), 176-177.

${ }^{46}$ France, "Matthew" dalam Morris, ed., The Tyndale New Testament, 256. 
seperti termaksud di atas, tampak dari kisah pembaptisan Kornelius (Kisah Para Rasul 10). Menurut kisah ini Petrus 25esame ijin supaya Kornelius dibaptiskan tanpa disunat dulu. Petrus mengambil keputusan yang demikian karena ia dibimbing oleh Tuhan (Kisah Para Rasul 10:9-29).

Setelah Yesus menanggapi pengakuan Petrus, Yesus melarang para muridNya untuk memberitahukan kepada siapapun bahwa Yesus adalah Mesias. Telah disebutkan, pengertian Petrus tentang Mesias yang dikenakan kepada Yesus berbeda dengan Mesias yang dimenegrti dan dinanti oleh orang-orang Yahudi. Menurut Petrus Yesus disebut Mesias karena Yesus adalah Hamba Allah yang kini 25esame untuk menyelamatkan semua kaum di bumi. Sedangkan bagi orang-orang Yahudi Mesias yang dimengerti dan dinanti adalah seorang raja yang 25esame untuk memusnahkan musuh-musuh Israel. Melihat pengertian tentang Mesias di kalangan umat Yahudi pada masa pelayanan Yesus adalah raja politis, maka larangan Yesus seperti tersebut di atas agaknya dimaksudkan untuk menghindari salah pengertian yang dapat timbul pada orang-orang Yahudi bahwa misi Yesus adalah mengangkat senjata untuk berperang melawan orang Romawi, sebab misi Yesus justru melenyapkan kebencian dan permusuhan di antara umat manusia.

Mempelajari kisah pengakuan Petrus di dapat pengertian bahwa Gereja adalah suatu paguyuban yang dikehendaki oleh Yesus berdasarkan pengakuan orang-orang bahwa Yesus adalah Mesias dan paguyuban yang diberi tanggung jawab oleh Yesus untuk menuntun umat manusia berada dalam suasana Kerajaan Sorga.

\section{Dari Kisah Perumpamaan Tentang Penggarap-penggarap Kebun Anggur}

Melalui perumpamaan tentang penggarap-penggarap kebun anggur, Yesus melukiskan sikap para pemimpin Yahudi beserta dengan rakyatnya sebagai orang-orang yang tidak bertanggung jawab dalam melaksanakan tugas yang dipercayakan Allah kepada meraka. Bangsa Yahudi ditugaskan oleh Allah untuk menjadi berkat bagi semua kaum di muka bumi (Kejadian 12:1-3), tetapi pada jaman Yesus mereka malah mengharapkan agar bangsa-bangsa yang menjadi musuh mereka dihancurkan. Yesus yang 25esame sebagai Mesias hamba untuk keselamatan dunia ditolaknya karena mereka menanti Mesias raja yang menyelamatkan Israel, namun menghancurkan bangsa-bangsa yang menjadi musuh Israel.

Dalam perumpamaan tentang penggarap-penggarap kebun anggur, Yesus mengemukakan bahwa, karena bangsa Yahudi gagal melaksanakan perannya bahkan menolak Yesus Kristus sebagai pembawa dan pewujud Keselamatan Allah, maka Kerajaan Allah akan diambil dari bangsa Yahudi dan akan diberikan kepada suatu bangsa yang akan menghasilkan buah Kerajaan itu (ayat 43). ${ }^{47}$ Yang dimaksud dengan suatu bangsa yang menghasilkan buah Kerajaan Allah adalah suatu bangsa yang menjelmakan nilai-nilai Kerajaan Allah. ${ }^{48}$ Kemudian yang dimaksud dengan bangsa yang menjelmakan nilai nilai Kerajaan Allah adalah Gereja yang terdiri dari orang-orang Israel yang percaya dan

\footnotetext{
${ }^{47}$ Matius 21:43, Markus 12:9, Lukas 20:16

${ }^{48}$ Tisera, "Faham Gereja Menurut Injil Matius" dalam Orientasi Baru Pustaka Filsafat dan Teologi, 96.
} 
menjadi pengikut Yesus dan orang-orang di luar Israel yang juga percaya dan menjadi pengikut Yesus (Bandingkan Matius 8:11). Berdasarkan penekanan kepada yang menghasilkan buah Kerajaan Allah, maka hakikat Gereja tidak harus dimengerti dalam arti tertutup, tetapi sebaliknya harus dipahami dalam arti terbuka. Artinya kapan saja dan dimana saja dapat terjadi masuknya orang yang semula dikategorikan sebagai bukan Gereja menjadi Gereja, sebagai akibat dari jawab mereka mengiyakan dan memberitakan Karya Penyelamatan Allah atau nilai-nilai Kerajaan Allah sebagaimana telah didemonstrasikan oleh Yesus. ${ }^{49}$ Sebaliknya kapan saja dan di mana saja dapat terjadi keluarnya orang-orang yang semula dikategorikan sebagai Gereja, menjadi bukan Gereja karena mereka tidak menghayati dan menjelmakan nilai-nilai Kerajaan Allah dalam kehidupan mereka. Pengertian yang demikian ini mendorong Gereja untuk tidak menjadi sombong secara spiritual, melainkan menjadi lebih memahami bahwa keberadaan dan panggilannya adalah sebagai alat dan sarana Allah untuk menghadirkan dan mewujudkan nilai-nilai Kerajaan Allah, berupa pembebasan, penyembuhan, pemulihan, dan pemanusiaan manusia. Dari perumapaan tentang penggarap-penggarap kebun anggur, tergambar bahwa Gereja adalah suatu komunitas yang terpanggil untuk mewujudkan tanda dan kharakter dari Kerajaan Allah. Bertolak dari pengertian yang demikian, jangan kita mengagungkan gereja dalam pengertian formal institusional, tetapi gereja dalam pengertian komunitas alternatif penghayat nilai-nilai kerajaan Allah.

\section{Penutup}

Berdasarkan uraian-uraian tentang hakikat Gereja dapat disimpulkan bahwa menurut Injil Injil Sinoptis, Gereja itu adalah sebuah paguyuban orang-orang yang menjawab ya terhadap panggilan Yesus untuk hidup bersamaNya dan diutus olehNya.Sebagai paguyuban orang-orang yang hidup bersama Yesus, Gereja adalah orangorang yang mengalami sendiri hidup bersama Yesus dan menempatkan segala sesuatu untuk kepentingan misi Yesus yakni mentransformasi dunia agar dunia ada dalam suasana pemerintahan Allah.

Sebagai paguyuban orang-orang yang diutus oleh Yesus, Gereja adalah orangorang yang tidak hanya hidup untuk keselamatan diri saja, melainkan juga orang-orang yang harus pergi kepada semua orang untuk mewartakan apa yang Yesus wartakan yaitu nilai-nilai Kerajaan Allah dengan perkatan dan perbuatan demi terciptanya peradaban dunia yang dijiwai oleh semangat pembebasan, pemulihan, penyembuhan, pendamaian dan pemanusiaan manusia.

Sebagai paguyuban orang-orang yang diutus oleh Yesus, Gereja adalah orangorang yang bukan mewartakan diri sendiri, juga bukan mewartakan karya sendiri, tetapi menghadirkan nilai-nilai Kerjaan Allah. Sebagai pewujud nilai-nilai Kerajaan Allah, Gereja adalah orang-orang yang dalam misinya harus membuat nilai pembebasan, penyembuhan, pemulihan, pendamaian dan pemanusiaan manusia, dapat dilihat dan dirasakan oleh 26esame demi kebahagiaan dan kedamaian dunia.

\footnotetext{
${ }^{49}$ Tridarmanto, Theologia Alkitab II, 107.
} 


\section{DAFTAR PUSTAKA}

Allen, Willoughby C. A Critical And Exegetical Commentary On The Gospel According To S. Matthew.Edinburgh: T \& T. Clark, 1951

Bauwer, Johanes B. Bauwer Encyclopedia of Biblical Theology. London: Sheed and Word, 1978

Bosch, David J. Transformasi Misi Kristen,Sejarah Teologi Misi Yang Mengubah Dan Berubah. Diterjemahkan oleh Stephen Suleeman. Jakarta: BPK Gunung mulia, 2011

Buttrick, George Arthur. The Interpreter's Dictionary of the Bible. New York: Abingdon Press, 1962

Carson, D.A. "Mathew" dalam Frank E. Gaebelem, The Expositor's Bible Commentary Vol. 8.Grand Rapids: Zondervan, 1984

Dister, Syukur. Kristologi Sebuah Sketsa. Yogyakarta: Kanisius, 1994

Ferguson, Sinclair. Understanding The Gospel.Eastbourne: Kingsway Publications, 1989

France, R.T. "Matthew" dalam Leon Morris, ed., The Tyndale New Testament Commentaries.Leicester: Inter Varsity Press, 1985

Groenen, C. Peristiwa Yesus. Yogyakarta, Kanisius, 1998

Jabocs, Tom. Siapa Yesus Kristus Menurut Perjanjian Baru. Yogyakarta: Kanisius, 1982

Jacobs Tom dan R. Sumadia. Injil Gereja Purba Tuhan Kita Yesus Kristus. Yogyakarta: Kanisius, 1975 205-206

Johnson, Sherman E. "The Gospel According to ST. Matthew" dalam G.A. Buttrick. The Interpreter's Bible.New York: Abiongdon Press, 1951

Kane, J. Herbert. Understanding Christian Missions, vo. 4. Grand Rapids: Baker Book House, 1990

Kingsbury, Jack Dean “The Figure of Peter in Matthew's Gospel as a Theological Problem. Journal of Biblical Literature.no. 98, 1979

Injil Matius Sebagai Ceritera, diterjemahkan oleh Wenas Kalangit. Jakarta: BPK Gunung Mulia, 1995

Kraybill, Donald B. Kerajaan Yang Sungsang. Diterjemahkan oleh Tobing dan Stepehen Suleeman. Jakarta: BPK, Gunung Mulia, 1993

Morris, Leon. New Testament Theology.Grand Rapids: Zondervan, 1986

Tanja, Victor I. "Perjumpaan Gereja Dengan Agama-Agama Lain" dalam Chris Hartono. Perjumpaan Gereja di Indonesia Dengan Dunianya Yang Sedang Berubah. Jakarta:Persetia,1995

Tisera, Guido "Faham Gereja Menurut Injil Matius" dalam Orientasi Baru Pustaka Filsafat dan Teologi no 2.Yogyakarta: Kanisius, 1988

Tridarmanto, Yusak. Theologia Alkitab II,.Yogyakarta: Diktat Kuliah, Mata Kuliah Theologia Perjanjian Baru, 1997

Woga, Edmund. Dasar-Dasar Misiologi. Yogyakarta: Penerbit Kanisius, 2006 